\title{
Sequential Postemergence Applications for the Control of Khakiweed in Bermudagrass Turf
}

\author{
Andrew J. Hephner, Tyler Cooper, Leslie L. Beck, \\ and Gerald M. Henry ${ }^{1}$ \\ Department of Plant and Soil Science, Texas Tech University, Box 42122, \\ Lubbock, TX 79409
}

Additional index words. golf course, weed control, sulfonylurea herbicides, trifloxysulfuron, metsulfuron, carfentrazone

\begin{abstract}
Khakiweed (Alternanthera pungens Kunth) response to single and sequential herbicide applications was evaluated during the summer of 2009 and 2010 in Texas. No bermudagrass phytotoxicity was observed throughout the length of each trial regardless of herbicide treatment. Carfentrazone at $0.034 \mathrm{~kg}$ a.i./ha, metsulfuron + carfentrazone at $0.021+0.034 \mathrm{~kg}$ a.i./ha, and trifloxysulfuron + carfentrazone at $0.018+0.034 \mathrm{~kg}$ a.i. $/ \mathrm{ha}$ exhibited $74 \%$ to $85 \%$ khakiweed control 2 weeks after initial treatment (WAIT) regardless of application regime. Control with carfentrazone $(0.017 \mathrm{~kg}$ a.i./ha) was only $63 \%$ to $65 \% 2$ WAIT regardless of application regime. Metsulfuron and trifloxysulfuron treatments exhibited $54 \%$ or less khakiweed control 2 WAIT regardless of rate. Six weeks later (8 WAIT), sequential applications of metsulfuron exhibited $98 \%$ control regardless of rate, whereas control with single applications was $79 \%$ to $87 \%$. Sequential applications of trifloxysulfuron exhibited $86 \%$ to $88 \%$ khakiweed control 8 WAIT regardless of rate, whereas single applications exhibited $47 \%$ or less control. Carfentrazone treatments exhibited $5 \%$ or less control regardless of rate or sequential application 8 WAIT. Tankmixing metsulfuron or trifloxysulfuron with carfentrazone did not improve control 8 WAIT compared with either sulfonylurea herbicide applied alone. Although initial khakiweed injury was observed in all treatments, effective long-term control was difficult to achieve. Excellent control $(95 \%$ to $97 \%)$ was exhibited by sequential metsulfuron applications 12 WAIT regardless of rate. Sequential applications of trifloxysulfuron $(0.018$ or $0.028 \mathrm{~kg}$ a.i./ha) and single applications of metsulfuron at $0.042 \mathrm{~kg}$ a.i./ha exhibited moderate khakiweed control (75\% to 80\%) 12 WAIT. All other treatments exhibited $57 \%$ or less khakiweed control 12 WAIT. Efficacy of sequential metsulfuron applications is a strong incentive for its adoption over trifloxysulfuron applications for the control of khakiweed in bermudagrass turf.
\end{abstract}

Khakiweed (Alternanthera pungens Kunth) is a perennial broadleaf weed that readily invades turfgrass throughout the arid and semiarid regions of the United States (McCarty et al., 2008). The presence of this weed significantly reduces the aesthetic value and playability of desired turfgrass species. Morphological characteristics and the ability to adapt to a wide range of environments have led to the increase in khakiweed prevalence in managed turf. Long-term reductions in turfgrass density often result from the aggressive spread of dense, prostrate khakiweed mats throughout the summer (Sholedice and Renz, 2006; Umeda and Towers, 2004). A deep taproot and a thick waxy cuticle help khakiweed avoid acute drought stress (Parsons and

Received for publication 5 July 2011. Accepted for publication 6 Jan. 2012

Texas Tech University manuscript no. T-4-616. We acknowledge the cooperation of Travis Williams, Aaron Holbrook, and Jeremy Rotramel for their technical assistance in this project. Appreciation is also extended to Mike Painter at Meadowbrook Golf Course in Lubbock, TX, for the use of his facility.

${ }^{1}$ To whom reprint requests should be addressed; e-mail gerald.henry@ttu.edu. conjunction with long-term reductions in new leaves and reproductive organs may be attributed to the accumulation of acetolactate synthase substrate (e.g., a-ke-tobutyrate) in leaf tissue (Brown, 1990; LaRossa and Van Dyk, 1987).

Trifloxysulfuron and metsulfuron are both labeled for the postemergence control of broadleaf weeds in warm-season turf (Anonymous, 2009, 2011). Minimal to no bermudagrass phytotoxicity was observed after applications of metsulfuron and trifloxysulfuron for weed control (Butler et al., 2005; Davis et al., 1997; Johnson, 1987; McElroy et al., 2005). Busey (2009) reported $77 \%$ control of dollarweed (Hydrocotyle umbellata L.) 10 WAIT in St. Augustinegrass [Stenotaphrum secundatum S. (Walt.) Kuntze] with applications of metsulfuron at $0.021 \mathrm{~kg}$ a.i./ha. Metsulfuron at $0.017,0.034$, and $0.05 \mathrm{~kg}$ a.i./ha exhibited $95 \%$ to $100 \%$ control of broom snakeweed [Gutierrezia sarothrae (Pursh) Britt. \& Rusby] present in pasture land 7 WAIT (McDaniel and Duncan, 1987). Singh and Singh (2004) observed 80\% to $88 \%$ control of redroot pigweed (Amaranthus retroflexus L.), Florida beggarweed [Desmodium tortuosum (Sw.) DC.], hairy beggarticks (Bidens pilosa L.), tall morning glory [Ipomoea purpurea (L.) Roth], and ivyleaf morningglory (Ipomoea hederacea Jacq.) in the greenhouse with applications of trifloxysulfuron at 0.063 $\mathrm{kg}$ a.i./ha. Trifloxysulfuron at $0.005 \mathrm{~kg}$ a.i./ha exhibited $73 \%$ control of sicklepod [Senna obtusifolia (L.) H.S. Irwin Barneby] 3 WAIT in the greenhouse (Koger et al., 2005).

Postemergence control of khakiweed with herbicides has received limited investigation. Trifloxysulfuron at $0.017,0.029$, and $0.053 \mathrm{~kg}$ a.i./ha exhibited $95 \%, 94 \%$, and $98 \%$ control, respectively, $40 \mathrm{~d}$ after treatment (DAT) (Kopec et al., 2004a). Single applications of metsulfuron at 0.021 and $0.042 \mathrm{~kg}$ a.i./ha exhibited 99\% khakiweed control 40 DAT (Kopec et al., 2004a). Penoxsulam at $0.1 \mathrm{~kg}$ a.i./ha exhibited $69 \%$ khakiweed control $40 \mathrm{~d}$ after initial treatment (DAIT) (Kopec et al., $2004 b$ ). Umeda (2008) observed 86\% khakiweed control 36 DAIT with applications of carfentrazone + 2,4-D + mecoprop + dicamba at $0.45 \mathrm{~kg}$ a.i./ha. Tank-mixing carfentrazone + 2,4-D + mecoprop + dicamba at $0.45 \mathrm{~kg}$ a.i./ha with fluroxypyr at $0.056 \mathrm{~kg}$ a.i./ha provided $85 \%$ khakiweed control 40 DAIT (Umeda and Towers, 2004). Applications of 2,4-D + mecoprop + dicamba at $0.14 \mathrm{~kg} / \mathrm{a}$.i. only controlled khakiweed 1\% 27 DAIT (Kopec et al., 2004a). Thus, carfentrazone may have potential for khakiweed control and warrants further investigation in bermudagrass.

The presence of a deep taproot enables khakiweed to regenerate from abundant carbohydrate reserves after defoliation (Umeda, 2008). Minimal research has examined sequential applications for the long-term control of khakiweed. Umeda (2008) reported 94\% khakiweed control $36 \mathrm{~d}$ after sequential treatment of carfentrazone $+2,4-\mathrm{D}+$ mecoprop + dicamba at $0.45 \mathrm{~kg}$ a.i./ha tank-mixed with isoxaben at $0.84 \mathrm{~kg}$ a.i./ha. Sequential applications may be necessary to reduce the photosynthetic capability of khakiweed and 
associated carbohydrate production to obtain long-term control of perennial plant portions. Therefore, the objective of our research was to examine single vs. sequential applications of various herbicides for long-term control of khakiweed in bermudagrass turf.

\section{Materials and Methods}

Field experiments were initiated in June 2009 and 2010 at Meadowbrook Golf Course in Lubbock, TX (lat. 33 $35^{\prime} 55^{\prime \prime} \mathrm{N}$, long. $\left.-101^{\circ} 49^{\prime} 52^{\prime \prime} \mathrm{W}\right)$. Research was performed on established khakiweed infestations present in a common bermudagrass [Cynodon dactylon (L.) Pers.] rough that was maintained at a height of $5.0 \mathrm{~cm}$. Plots measured $1.5 \times 1.5 \mathrm{~m}$ and were arranged in a randomized complete block design with four replications. Initial khakiweed cover ( $40 \%$ to $90 \%$ ) was assessed for each plot before herbicide application through grid counts. All experimental areas were mowed once weekly. There was no rain or irrigation applied for a 24 -h period after herbicide applications.

Fourteen herbicide treatments and a nontreated control were included in both years of the study (Table 1). Herbicide treatments were initiated on 9 June 2009 and 10 June 2010. Herbicides included trifloxysulfuron (Monument; Syngenta Crop Protection, LLC, Greensboro, NC), carfentrazone (Quicksilver; FMC Corporation, Philadelphia, PA), and metsulfuron (Blade; PBI Gordon Corporation, Kansas City, MO) (Table 1). Treatments were applied using a $\mathrm{CO}_{2}$-pressurized backpack sprayer equipped with XR8004VS Teejet nozzle tips (Teejet, flat-fan extended-range spray tips; Spraying Systems Co., Wheaton, IL) calibrated to deliver $375 \mathrm{~L} \cdot \mathrm{ha}^{-1}$ at $221 \mathrm{kPa}$.

Data collected included bermudagrass phytotoxicity and khakiweed control based on digital image analysis and grid counts, respectively. Digital photographs were taken 1, 2, 4,
6,7 , and 8 WAIT with a Nikon (Coolpix P5000; Nikon Inc. USA, Melville, NY) 10.0megapixel camera mounted on a light box equipped with four incandescent light bulbs each with a light output of $172 \mu \mathrm{mol} \cdot \mathrm{m}^{-2} \cdot \mathrm{s}^{-1}$. Digital images were analyzed using WinCam 2007 software (Regent Instruments Inc., Quebec, Canada) to determine the percentage of bermudagrass leaf firing (chlorotic tissue) per plot. Percent bermudagrass leaf firing data were converted to percent bermudagrass phytotoxicity by comparing values for each plot with the untreated control within each experimental replication. Grid counts were taken $1,2,4,6,8$, and 12 WAIT using a $0.3-\mathrm{m}^{2}$ grid (25 intersecting points) tossed into each plot [e.g., 15 plants equal $60 \%$ cover $\left.\left(15 / 25^{*} 100\right)\right]$. Khakiweed cover from grid counts was converted to percent khakiweed control by comparing khakiweed cover for each plot with the cover recorded at initial herbicide application. Percent bermudagrass phytotoxicity and percent khakiweed control were arcsine square root transformed before analysis. Transformation did not improve variance homogeneity; therefore, non-transformed data were used in analysis and presentation. There were no significant year-by-treatment interactions, so data were combined and subjected to analysis of variance using error partitioning appropriate to a randomized complete block design analysis in the general linear models procedure provided by SAS (SAS, Statistical Analysis Systems, 2002-2008, Release 9.2; Statistical Analysis Systems Institute, Cary, NC). Means were separated using Fisher's protected least significant difference at the 0.05 significance level.

\section{Results and Discussion}

No bermudagrass phytotoxicity was observed throughout the length of each trial regardless of herbicide treatment (data not

Table 1. Control of khakiweed (Alternanthera pungens Kunth) in bermudagrass 2, 8, and 12 WAIT at Meadowbrook Golf Course (Lubbock, TX) in 2009 and 2010. ${ }^{\mathrm{z}}$

\begin{tabular}{|c|c|c|c|c|}
\hline Treatment $^{\mathrm{y}}$ & $\begin{array}{c}\text { Rate } \\
\text { (kg a.i./ha) }\end{array}$ & 2 WAIT & $\begin{array}{c}8 \text { WAIT } \\
(\% \text { control })\end{array}$ & 12 WAIT \\
\hline Trifloxy $^{\mathrm{x}}$ & 0.018 & 32 & 30 & 22 \\
\hline Trifloxy & 0.028 & 50 & 47 & 28 \\
\hline Trifloxy $\mathrm{fb}^{\mathrm{w}}$ Trifloxy 5 WAIT & $0.018+0.018$ & 37 & 86 & 75 \\
\hline Trifloxy fb Trifloxy 5 WAIT & $0.028+0.028$ & 53 & 88 & 80 \\
\hline Carfen $^{\mathrm{v}}$ & 0.017 & 65 & 0 & 0 \\
\hline Carfen & 0.034 & 82 & 0 & 0 \\
\hline Carfen fb Carfen 5 WAIT & $0.017+0.017$ & 63 & 0 & 0 \\
\hline Carfen fb Carfen 5 WAIT & $0.034+0.034$ & 85 & 5 & 0 \\
\hline $\mathrm{Met}^{\mathrm{u}}$ & 0.021 & 42 & 79 & 57 \\
\hline Met & 0.042 & 54 & 87 & 79 \\
\hline Met $\mathrm{fb}$ Met 5 WAIT & $0.021+0.021$ & 41 & 98 & 95 \\
\hline Met $\mathrm{fb}$ Met 5 WAIT & $0.042+0.042$ & 53 & 98 & 97 \\
\hline Met + Carfen & $0.021+0.034$ & 78 & 60 & 42 \\
\hline Trifloxy + Carfen & $0.018+0.034$ & 74 & 26 & 9 \\
\hline Nontreated & - & 0 & 0 & 0 \\
\hline Least significant difference $(P=0.05)$ & - & 6 & 6 & 5 \\
\hline
\end{tabular}

${ }^{\mathrm{z}}$ Control estimates are based on grid counts. Data were pooled over experiments conducted in 2009 and 2010. WAIT $=$ weeks after initial treatment.

${ }^{y}$ Single or sequential applications were made with each application within a treatment receiving the same herbicide rate.

xtrifloxy $=$ trifloxysulfuron

${ }^{\mathrm{w}} \mathrm{fb}=$ followed by

varfen $=$ carfentrazone

umet $=$ metsulfuron. shown). Johnson (1987) observed similar results on bermudagrass in response to metsulfuron at $0.03,0.07$, and $0.13 \mathrm{~kg}$ a.i./ha, whereas McElroy et al. (2005) reported bermudagrass seedling tolerance $(13 \%$ or less phytotoxicity) to trifloxysulfuron applications at $0.03 \mathrm{~kg}$ a.i./ha.

Herbicide treatment main effects were observed for khakiweed control (Table 1). Carfentrazone at $0.034 \mathrm{~kg}$ a.i./ha, metsulfuron + carfentrazone at $0.021+0.034 \mathrm{~kg}$ a.i./ha, and trifloxysulfuron + carfentrazone at $0.018+$ $0.034 \mathrm{~kg}$ a.i. $/$ ha exhibited $74 \%$ to $85 \%$ khakiweed control 2 WAIT regardless of application regime. Umeda (2008) observed similar results (72\% khakiweed control 10 DAIT) with applications of carfentrazone $+2,4-\mathrm{D}+$ mecoprop + dicamba at $0.45 \mathrm{~kg}$ a.i./ha. Weeds treated with carfentrazone often exhibit necrosis and die within a few days (Senseman and Armbrust, 2007). Carfentrazone alone (0.017 $\mathrm{kg}$ a.i./ha) in our research exhibited $63 \%$ to $65 \%$ control 2 WAIT regardless of application regime. However, metsulfuron and trifloxysulfuron treatments exhibited $54 \%$ or less khakiweed control 2 WAIT regardless of rate. Injury symptoms after application of metsulfuron and trifloxysulfuron have been reported to take greater than 1 to 2 weeks to appear (Senseman and Armbrust, 2007).

Six weeks later (8 WAIT), sequential applications of metsulfuron exhibited $98 \%$ control regardless of rate, whereas control with single applications of metsulfuron was only $79 \%$ to $87 \%$. Kopec et al. (2004a) reported a similar response in khakiweed control (99\%) 40 DAT with single applications of metsulfuron at 0.021 and $0.042 \mathrm{~kg}$ a.i./ha. Sequential applications of trifloxysulfuron exhibited $86 \%$ to $88 \%$ khakiweed control 8 WAIT regardless of rate, whereas single applications exhibited $47 \%$ or less control. These findings differ from those of Kopec et al. (2004a) who observed $94 \%$ to $99 \%$ khakiweed control 40 DAT with applications of trifloxysulfuron at 0.017, 0.029, and $0.053 \mathrm{~kg}$ a.i./ha. Carfentrazone treatments exhibited $5 \%$ or less khakiweed control regardless of rate or sequential application 8 WAIT. Tank-mixtures of metsulfuron or trifloxysulfuron with carfentrazone did not improve control 8 WAIT compared with either sulfonylurea herbicide applied alone. Rapid burn-down of khakiweed foliage in response to carfentrazone may reduce sulfonylurea translocation, therefore decreasing long-term control. Hutchinson et al. (2006) theorized a similar mechanism for metribuzin safening the phytotoxic effects of sulfentrazone applied postemergence to potatoes. Metribuzin may cause rapid cell disintegration, which in turn inhibits sulfentrazone translocation, resulting in less total sulfentrazone injury (Hutchinson et al., 2006).

Although initial khakiweed injury was observed with all treatments, effective longterm control was difficult to achieve. Excellent control ( $95 \%$ to $97 \%$ ) was exhibited by sequential metsulfuron applications 12 WAIT regardless of rate. Sequential applications of trifloxysulfuron ( 0.018 or $0.028 \mathrm{~kg}$ a.i./ha) and single applications of metsulfuron at $0.042 \mathrm{~kg}$ 
a.i./ha exhibited moderate khakiweed control ( $75 \%$ to $80 \%) 12$ WAIT. All other treatments exhibited $57 \%$ or less khakiweed control 12 WAIT. Previous research has only examined khakiweed control over shorter time periods (49 DAT or less) (Kopec et al., 2004a, 2004b; Umeda, 2008; Umeda and Towers, 2004).

Khakiweed produces a deep taproot used to store carbohydrates for emergence and growth in subsequent years. Effective khakiweed control is likely limited by absorption and translocation of applied herbicides. Leys and Slife (1988) reported 58\% of applied ${ }^{14} \mathrm{C}$ metsulfuron was readily absorbed by wild garlic (Allium vineale L.) $144 \mathrm{~h}$ after application and $16 \%$ of that absorbed material translocated out of the treated leaf. Troxler et al. (2003) observed 53\% or less of applied ${ }^{14} \mathrm{C}$-trifloxysulfuron was absorbed by yellow nutsedge (Cyperus esculentus L.) and purple nutsedge (C. rotundus L.) $96 \mathrm{~h}$ after treatment. Approximately $30 \%$ of the absorbed ${ }^{14} \mathrm{C}$-trifloxysulfuron translocated out of both Cyperus spp.-treated leaves with 4\% moving into tubers and roots. McElroy et al. (2004) observed similar results in green kyllinga ( $\mathrm{Kyl}$ linga brevifolia Rottb.) and false-green kyllinga (Kyllinga gracillima Miq.). Both spp. absorbed $47 \%$ of the applied ${ }^{14} \mathrm{C}$-trifloxysulfuron $96 \mathrm{~h}$ after application. Approximately $2 \%$ and $4 \%$ of the absorbed ${ }^{14} \mathrm{C}$-trifloxysulfuron translocated to the roots and rhizomes, respectively. Substantial amounts of translocation exhibited by metsulfuron and trifloxysulfuron in other weed species may explain the amount of khakiweed control observed in this research.

Long-term (12 WAIT) khakiweed control efficacy with sequential metsulfuron applications is a strong incentive for its adoption over trifloxysulfuron for selective khakiweed control in bermudagrass turf. Although sequential trifloxysulfuron applications may provide moderate $(80 \%)$ khakiweed control, remaining plants exhibit carbohydrate production and storage necessary for the emergence of new plants the next year. Enhanced khakiweed control 2 WAIT with carfentrazone warrants further research. Applications of trifloxysulfuron or metsulfuron after carfentrazone treatment may offer improved control of this perennial weed.

\section{Literature Cited}

Anonymous. 2009. Monument ${ }^{\mathrm{TM}}$ herbicide product label. Syngenta Crop Protection, Inc., Greensboro, NC.

Anonymous. 2011. Blade ${ }^{T M}$ herbicide product label. PBI/Gordon Corp., Kansas City, MO.

Beyer, E.M., Jr., M.J. Duffy, J.V. Hay, and D.D. Schlueter. 1988. Sulfonylurea, p. 117-189. In: Kearney, P.C. and D.D. Kaufman (eds.). Herbicide chemistry, degradation, and mode of action. Vol. 3. Marcel Dekker, Inc., New York, NY.

Brown, H.M. 1990. Mode of action, crop selectivity, and soil relations of the sulfonylurea herbicides. Pestic. Sci. 29:263-281.

Busey, P. 2009. Irrigation interval and herbicide reduces dollarweed (Hydrocotyle umbellate) in St. Augustinegrass (Stenotaphrum secundatum) turf. Intl. Turf. Soc. 11:1167-1175.

Butler, J.T., J.P. Ducar, and J. Tredaway. 2005. Weed control and response to herbicides during 'Tifton 85 ' bermudagrass establishment from rhizomes. Agron. J. 98:788-794.

Davis, S.D., R.R. Duncan, and B.J. Johnson. 1997. Suppression of seashore paspalum in bermudagrass with herbicides. J. Environ. Hort. 15:187190.

Hutchinson, P.J.S., B.R. Beutler, and D.M. Hancock. 2006. Weed control and potato (Solanum tuberosum) crop response with low rates of sulfentrazone applied postemergence with metribuzin. Weed Technol. 20:1023-1029.

Johnson, B.J. 1987. Turfgrass species response to herbicides applied postemergence. Weed Technol. 1:305-311.

Koger, C.H., A.J. Price, and K.N. Reddy. 2005 Weed control and cotton response to combinations of glyphosate and trifloxysulfuron. Weed Technol. 19:113-121.

Kopec, D.M., J.J. Gilbert, and M. Pessarakli. 2004a. Penoxsulam as a potential post-emergence for khakiweed (Alternanthera pungens). University of Arizona College of Agriculture Turfgrass and Ornamental Research Report. 17 Apr. 2011. $<$ http://cals.arizona.edu/pubs/crops/az1359/>.

Kopec, D.M., J. Gilbert, M. Pessarakli, and J. Moreno. 2004b. Late season application for efficacy screening of select herbicides for post-emergence control of khakiweed. University of Arizona College of Agriculture Turfgrass and Ornamental Research Report. 17 Apr. 2011. <http://cals. arizona.edu/pubs/crops/az1359/>.
LaRossa, R.A. and T.K. Van Dyk. 1987. Metabolic mayhem caused by 2-ketoacid imbalances. Bioessays 7:125-130.

Leys, A.R. and F.W. Slife. 1988. Absorption and translocation of ${ }^{14} \mathrm{C}$-chlorsulfuron and ${ }^{14} \mathrm{C}$ metsulfuron in wild garlic (Allium vinexle). Weed Sci. 36:1-4.

McCarty, L.B., J.Q. Everest, D.W. Hall, T.R. Murphy, and F. Yelverton. 2008. Color atlas of turfgrass weeds. 2nd Ed. Ann Arbor Press, Chelsea, MI. p. 432.

McDaniel, K.C. and K.W. Duncan. 1987. Broom snakeweed (Gutierrezia saothrae) control with picloram and metsulfuron. Weed Technol. 35: 837-841.

McElroy, J.S., G.K. Breeden, F.H. Yelverton, T.W Gannon, S.D. Askew, and J.F. Derr. 2005. Response of four improved seeded bermudagrass cultivars to postemergence herbicides during seeded establishment. Weed Technol. 19:979-985.

McElroy, J.S., F.H. Yelverton, I.C. Burke, and J.W. Wilcut. 2004. Absorption, translocation, and metabolism of halosulfuron and trifloxysulfuron in green kyllinga (Kyllinga brevifolia) and false-green kyllinga (K. gracillima). Weed Sci. 52:704-710.

Parsons, W.T. and E.G. Cuthbertson. 2001. Khaki weed, p. 158-159. In: Noxious weeds of Australia. CSIRO Pub., Collingwood, Victoria, Australia. Senseman, S.A. and K. Armbrust. 2007. Herbicide handbook. Weed Science Society of America, Lawrence, KS. p. 94.

Sholedice, F. and M. Renz. 2006. Khakiweed. New Mexico State Univ. O \& T Guide W-8. Cooperative Extension Service. College of Agric. \& Home Economics, Las Cruces, NM. p. 1-2.

Singh, S. and M. Singh. 2004. Effect of growth stage on trifloxysulfuron and glyphosate efficacy in twelve weed species of citrus groves. Weed Technol. 18:1031-1036.

Troxler, S.C., I.C. Burke, J.W. Wilcut, W.D. Smith, and J. Burton. 2003. Absorption, translocation, and metabolism of foliar-applied CGA-362622 in purple and yellow nutsedge (Cyperus rotundus and C. esculentus). Weed Sci. 51:13-18.

Umeda, K. 2008. Evaluation of herbicides for khakiweed control. Turfgrass, Landscape and Urban IPM Research Summary. p. 25-29.

Umeda, K. and G. Towers. 2004. Evaluation and comparison of spotlight* herbicide combinations for khakiweed control in turf. University of Arizona College of Agriculture Turfgrass and Ornamental Research Report. 14 Apr. 2011. $<$ http://cals.arizona.edu/pubs/crops/az1359/>. 